
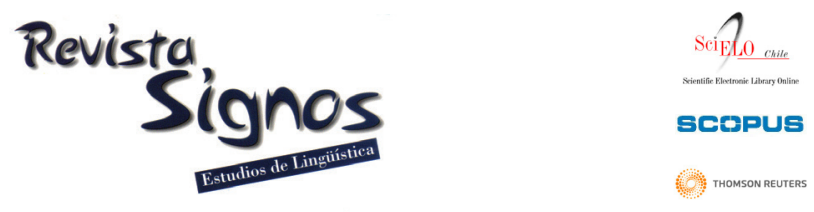

\title{
A connectionist approach to functional-cognitive linguistics: Spanish pronominal clitics and verb endings in relational-network terms
}

Una aproximación conexionista a la lingüistica cognitivo-funcional: Clíticos pronominales y desinencias verbales del español en términos de redes relacionales

\author{
Adolfo Martín García \\ Consejo Nacional de Investigaciones Científicas y Técnicas (Argentina) \\ Facultad de Educación Elemental y Especial (UNCuyo, Argentina) \\ Laboratorio de Psicología Experimental y Neurociencias (INECO, Argentina) \\ Núcleo UDP-Fundación INECO para las Neurociencias (UDP, Chile) \\ adolfomartingarcia@gmail.com
}

Recibido: 27-XII-2013 / Aceptado: 16-I-2015

\begin{abstract}
The Spanish pronominal clitic and verb-ending systems have been widely treated in the functional and cognitive linguistics literature. However, they have rarely been jointly modeled from a network-based perspective. Moreover, the only previous attempt to characterize the systems' architecture in network terms presents a number of limitations. This paper presents a preliminary relational-network-based model of the main semantic, morphological, and morphotactic aspects of both systems. An explicit distinction is introduced among several types of cognitive relationships operating at different levels of the systems, as follows: (i) the relationships between the relevant semantic categories and their associated features are disjunctive, thus involving downward 'or' nodes; (ii) whereas explicit, context-independent meanings involve simple downward 'or' nodes, implicit, context-dependent messages call for complex disjunctive relationships in which an upward 'or' node is then connected to downward 'or' node; (iii) the relationships representing morphotactic patterns are sequential conjunctions, thus involving ordered 'and' nodes; and (iv) the relationships established between a constellation of semantic features and the morphological representation realizing it in a specific context of use are simultaneous conjunctions, thus involving unordered 'and' nodes. The model constitutes the first relational-network account of the cognitive relationships holding together the Spanish pronominal clitic and verbending systems.
\end{abstract}

Key Words: Relational network theory, connectionism, Spanish, clitics, verb endings. 


\section{Resumen}

Los sistemas de clíticos pronominales y desinencias verbales del español han sido ampliamente abordados en la lingüística funcionalista y cognitivista. Sin embargo, rara vez se los ha modelizado conjuntamente desde una perspectiva reticular. A su vez, el único antecedente en la literatura presenta diversas limitaciones. En este artículo se recurre a la teoría de redes relacionales para esbozar un modelo superador de los principales aspectos semánticos, morfológicos y morfotácticos de ambos sistemas. Específicamente, se distingue entre varios tipos de relaciones cognitivas que operan en diferentes niveles, a saber: (i) las relaciones entre las categorías semánticas pertinentes y sus rasgos asociados son disyuntivas, de modo que involucran nodos 'o' descendentes; (ii) mientras que los significados explícitos (independientes del contexto) implican nodos 'o' descendentes individuales, los mensajes implícitos (dependientes del contexto) involucran relaciones disyuntivas complejas en las que un nodo 'o' ascendente se conecta con un nodo 'o' descendente; (iii) las relaciones que representan patrones morfotácticos constituyen conjunciones secuenciales, de modo que suponen nodos ' $y$ ' ordenados; y (iv) las relaciones establecidas entre una constelación de rasgos semánticos y la representación morfológica que la realiza en un contexto de uso determinado son conjunciones simultáneas, o sea que involucran nodos ' $y$ ' no ordenados. El modelo supone la primera caracterización basada en redes relacionales de las conexiones cognitivas que sustentan a los sistemas de clíticos pronominales y desinencias verbales del español.

Palabras Clave: Redes relacionales, conexionismo, español, clíticos, desinencias verbales.

\section{INTRODUCTION}

Pronominal clitics and verb endings play a distinguishing role in Spanish verb morphology. Spanish pronominal clitics are units intermediate between independent words and bound morphemes. They can fulfill independent grammatical functions (e.g., as direct or indirect objects), but they have no phonological autonomy (i.e., they are always unstressed and are typically pronounced in the same tone group as the verb). For their part, Spanish verb endings are verb desinences which necessarily express 'person' and 'number' and which, optionally, may also express 'mood', 'tense', and 'aspect'. These two sets of features may be realized by a single morpheme (García, 1975, 2009). Consider the sentence in bold within the following text -this and all following examples are real texts taken from the Real Academia Española's Corpus de referencia del español actual (CREA):

(1) Una hora después del partido del miércoles, el técnico Francisco Maturana ya tenía elegidos a los reemplazantes de los expulsados Perea y Ricardo Pérez; así nos lo confesó [He confessed it to us] [RAE: CREA, Clarín, 03/07/1987: Intimidad de los rivales]. 
In (1), nos and 10 are clitics acting as indirect and direct objects, respectively. The ending - 0 , instead, realizes several semantic features of the main verb, such as 'third person singular', 'indicative mood', 'past tense' and 'perfective aspect'. Still, Spanish clitics and verb endings share several attributes which warrant their joint treatment. Semantically, both types of unit realize features pertaining to at least six common categories (see 2.1) ${ }^{1}$. Morphologically, they are all monomorphemic units ${ }^{2}$. Morphotactically, they all occur either attached to or in the immediate proximity of the verb; while endings are always suffixed to the verb, clitics may occur either before the verb -when the latter is in the indicative or in virtually all uses of the subjunctiveor after the verb -when the latter is in the infinitive, imperative, or gerundial form, or in the subjunctive when conveying polite orders (Fernández Soriano, 1999).

García (2009) refers to the morphological link between a clitic and its associated verb as a verb complex, and considers that the verb's ending is the grammatical heart of such a structure. The bondage between a clitic and a verb indicates that the referent of the former is a participant of the event denoted by the latter. In a verb complex, verb endings are privileged in that they are the only form possessing inflectional properties.

Previous studies have shown and discussed other distinctive properties of Spanish pronominal clitics. For instance, the same clitic cannot attach to the same verbal form more than once -e.g., the cluster *me me is ungrammatical (García, 2009). Also, successive clitics always occur in a fixed order, namely se -2 nd person singular- 1 st person singular -3 rd person singular- $l$ - clitic (Enrique-Arias, 2005). Furthermore, no variety of Spanish admits the cluster *le lo, even though cognate forms can be thus arranged in typologically close languages, such as French. In Spanish, the successive combination of two 3rd person singular clitics in the dative and accusative cases, respectively, results in a cluster headed by the so-called 'spurious se', as opposed to le(s) (Piera \& Varela 1999).

Interestingly, some clitic clusters are acceptable only when certain interpretive conditions apply. For example, *me le is unacceptable when the direct object and the subject refer to different entities (e.g., *me le recomendaste), but it proves acceptable when such constituents are co-referential (e.g., *me le entreguê) (Bello, 1980; Bonet, 1994; Haspelmath, 2004). Accounting for the conditions which render a cluster acceptable or unacceptable has become a focus of interest for functional linguists (for a discussion, see García, 2009) and a theoretical challenge to formal grammarians (Harris, 1996). In addition, several works within the functional-cognitive literature have examined Spanish clitics and verb endings by focusing on their syntacto-pragmatic (Belloro, 2007), compositional-interpretive (García, 2009), stylistic (Aijón Oliva \& Serrano, 2010), and variational (Martínez, 2010) aspects.

However, the exploration of the 'network connections' underlying these systems has been very limited. To the best of my knowledge, the only network-based model 
of these systems semantic-lexicogrammatical interface is found in Castel (2012). Working within Communicative Mind Model (CMM) (Fawcett, 2011, 2013), (Castel, 2012) draws on systemic-functional categories to characterize relevant connections. Figure 1 (adapted from Castel, 2012) succinctly represents the architecture of the generative components of the CMM.

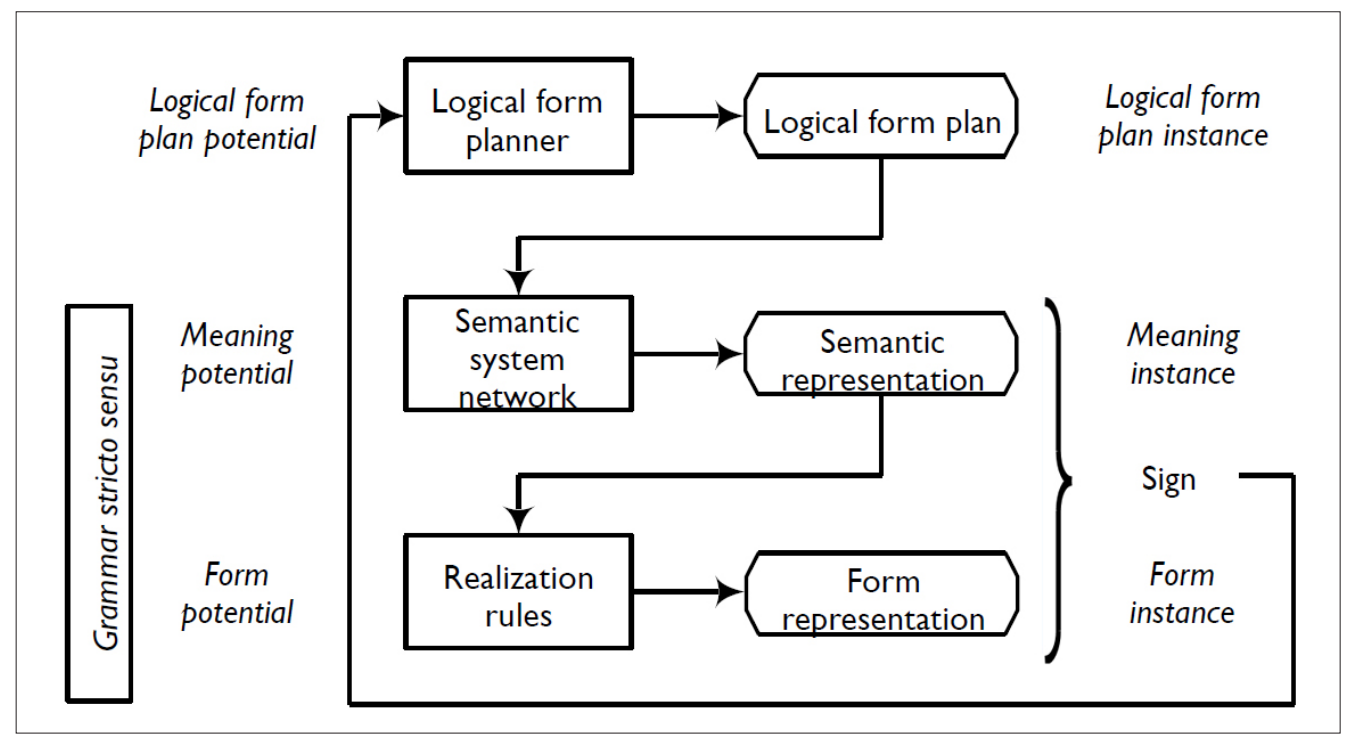

Figure 1. Generative components of the CMM (adapted from Castel, 2012: 167).

Castel (2012) observes that extant systemic-functional models have not provided explicit visualizations of the meaning-form interface. In this sense, the author makes a valuable contribution to the functional-cognitive literature by offering the first network-based account of the interstratal relationships of exponence, filling, and componence, as defined in Fawcett (2000). Specifically, he addresses the domain of Spanish clitics and verb endings, on the basis of García's (1975) classical description. His approach is exemplified in Figure 2 (Castel, 2012), which captures the relationships among the semantic and form-level representations involved in the production of $m e$ le regalo ['I give myself to him as a gift'].

Figure 2 illustrates three types of relationships: (i) relationships among semantic categories, governed by the node ' $\mathrm{Ev} 0$ '; (ii) relationships among form categories, governed by the node ' $\mathrm{Cl}$ '; and (iii) relationships among both types of categories, represented by connections between terminal semantic and form categories. Moreover, the network features a number of theoretical assumptions and descriptive limitations, as follows.

First, the network is unidirectional, as its connections account only for production, as opposed to comprehension, processes. Second, it fails to discriminate 
among different types of nodes and connections. All of its nodes receive and send information in the same manner, there being no distinction between simultaneous and sequential processes. For example, the connections stemming from the ' $\mathrm{Cl}$ ' node must specify serial ordering, as clause constituents appear in a strict sequence, one after the other. Instead, the semantic features 'singular', 'thematic', 'performer', 'nonfeminine', and 'least active' are simultaneously activated in the processing of the form me. Such connectivity distinctions are absent in this network.

Third, the network inherits from the CMM the assumption that form units are inserted into slots within a predefined scheme of syntactic positions. The only node specifying form-level information is ' $\mathrm{Cl}$ '. Its dependent connections represent instructions to distribute lexicogrammatical objects. For instance, the fourth line stemming from the ' $\mathrm{Cl}$ ' node indicates that the unit expounding the verb ending ('Vnd') will be located in position 6 of the syntactic scheme ('at_6_CoBy'). Similarly, other objects fill slots 5, 4, and 3. Thus, the network suggests that at some stage in the sentence-generation process, speakers construct a form representation including both 'filled' and 'empty' syntactic positions.

Finally, this network assumes that the systems are highly redundant, as there are several nodes and connections representing the exact same information. For example, there are three different nodes for the feature 'singular', two for 'non-thematic', and two for 'non-feminine'. It follows from this conceptualization that the same semantic information (e.g., the feature 'singular') exists multiple times in the speaker's semantic system, and that each of its instances is connected exclusively with one specific form representation. 


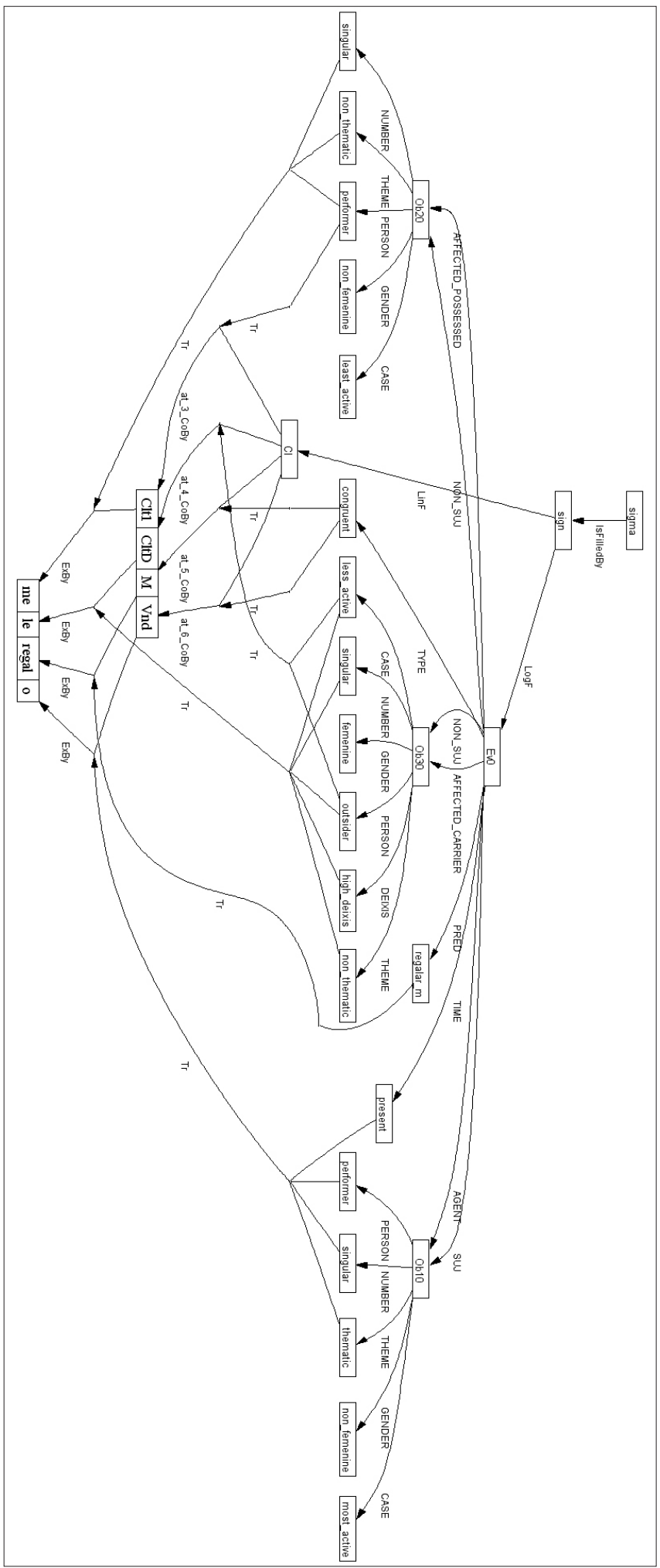

Figure 2. Network account of me le regalo in CMM terms (Castel, 2012: 172). 
All in all, Castel's (2012) network approach constitutes an important contribution to the functional-cognitive treatment of meaning-form mappings, in general, and the Spanish clitic and verb-ending systems, in particular. However, this innovative approach presents at least four descriptive assumptions which can be improved in the quest for cognitive plausibility, namely: (i) unidirectionality, (ii) node uniformity, (iii) syntactic slot-filling, and (iv) representational redundancy. These limitations may be overcome by adopting a conspicuous connectionist model. This paper builds upon Castel's approach to provide a more explicit characterization of the functionalcognitive structure underlying both systems, from the perspective of Relational Network Theory (RNT) (Lamb, 1966, 1999; García \& Gil, 2011a).

\section{Relational network theory}

RNT (Lamb, 1966, 1999; García \& Gil, 2011a) is a connectionist theory based on Hjelmslev's (1961 [1943]) glossematics. RNT seeks to describe linguistic structure in neurocognitively plausible terms. ${ }^{3}$ It posits that a realistic model must satisfy three requisites: (i) operational plausibility (it must explain how the system produces and comprehends texts in real time); (ii) developmental plausibility (it must account for how linguistic systems are construed throughout life); and (iii) neurological plausibility (it must prove that its constructs have explicit neural correlates). Accordingly, RNT frames language as a subsystem within the global model of human cognition shown in Figure 3 (Lamb, 1999).

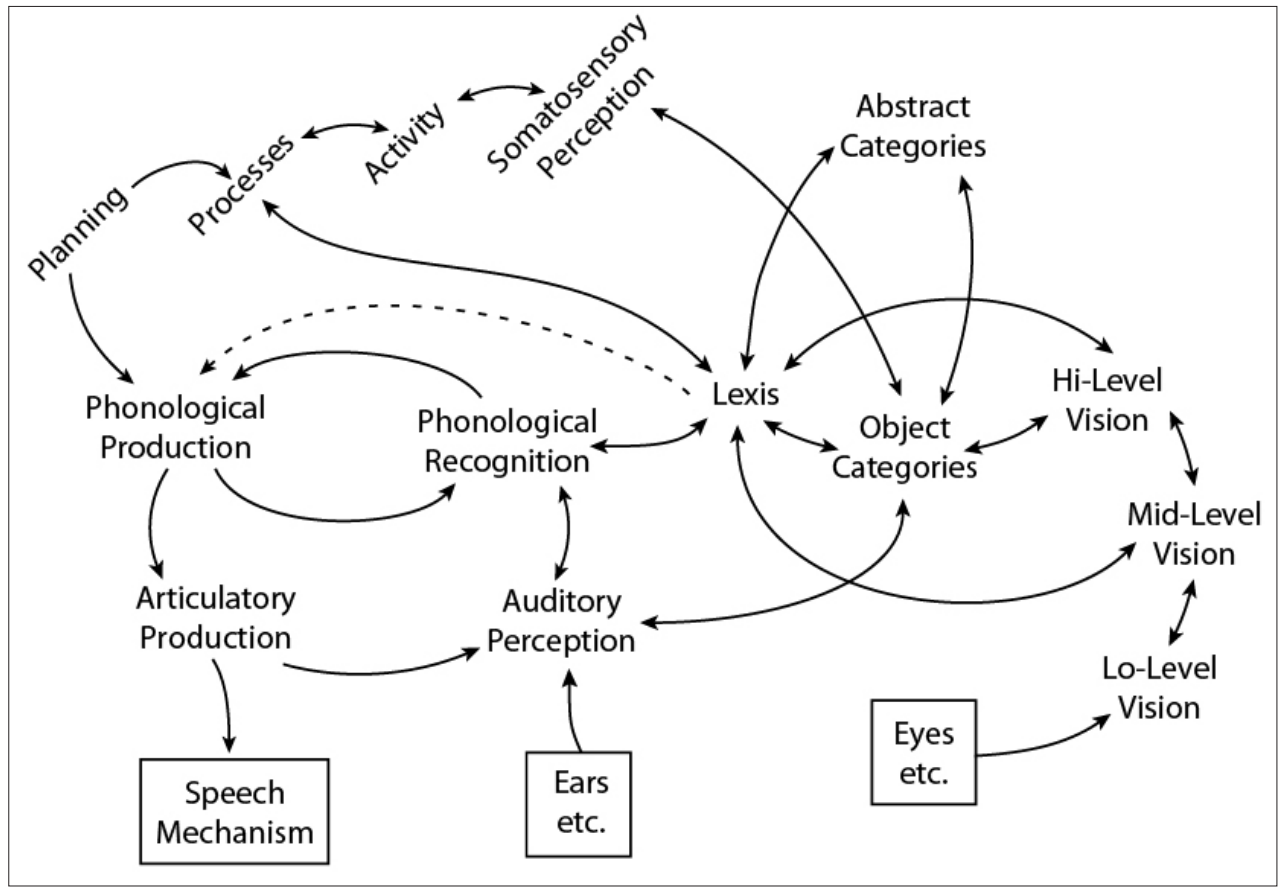

Figure 3. Language in relation to other cognitive systems (taken from Lamb, 1999: 140). 
The previous diagram shows the connections between some linguistic subsystems (e.g., Phonological Production, Phonological Recognition, Lexis), other cognitive subsystems (e.g., Auditory Perception and several visual systems), and even the sensory organs functioning as interfaces with the extra-mental world (e.g., ears and eyes). While an extended discussion of Figure 3 is beyond the scope of this paper, it is relevant to highlight two of its assumptions: (i) the semantic system (Object Categories, Abstract Categories) is bidirectionally connected to the lexical and grammatical components, and (ii) the lexical system (Lexis) is bidirectionally connected to the components of the grammatical system.

From a RNT perspective, each of these components consists of nothing but relationships. Unlike verbal productions, the cognitive representation of linguistic information is characterized as a network of connections. The objects or symbols with which linguists analytically describe verbal behavior only exist as such outside the cognitive system proper. The linguistic system in our minds is conceived of as a relational network whose connectivity patterns enable it to both produce and understand external symbols. Thus, in order to account for the cognitive structure of a linguistic system one must characterize the different types of connections it includes (Lamb, 1999; García \& Gil, 2011a).

In RNT, relationships are diagrammed with lines and nodes. Lines represent connections allowing for the flow of activation in and out of the nodes. Nodes are classified according to three dimensions of contrast, namely: type ('and' vs. 'or'), orientation ('upward' vs. 'downward'), and ordering ('ordered' vs. 'unordered'). Biologically speaking, activation takes the form of electrochemical signals traveling through neuron circuits in the brain.

'And' nodes are represented with triangles, whereas 'or' nodes are represented with horizontal brackets. Each node has a singular and a plural side, determined by the number of nodes each side is connected to. The singular side of a node is the one possessing just one connecting line. The position of the plural side (the side linked to at least two other nodes) dictates the node's orientation: if the plural side faces upwards, then the node is 'upward'; if the plural side faces downwards, then the node is 'downward'. However, in compact notation (i.e., the notation system used throughout this paper) 'all nodes are bidirectional', regardless of their orientation. For example, within the lexicogrammatical stratum, both 'upward' and 'downward' nodes can send activation to a higher stratum (i.e., the semantic system) and to a lower stratum (i.e., the phonological system). Similarly, within the phonological stratum, both types of nodes can send activation above (to lexicogrammatical nodes) or below (to phonetic nodes).

Lastly, a node is 'ordered' if its connecting lines converge in (or stem from) different points on the node's plural side, implying that each line will be activated sequentially, one after the other. On the contrary, a node is 'unordered' if its connecting lines 
converge in (or stem from) one and the same point on the node's plural side, implying that all such lines will be activated simultaneously. Figure 4 exemplifies the main types of relationships postulated by RNT in compact notation and explains their respective functioning.

Upward

Unordered and

$\mathrm{b}$

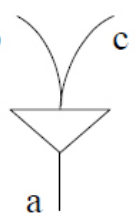

Upward activation

from a goes to $\mathrm{b}$ and $\mathrm{c}$.

Downward activation

from $\mathrm{b}$ and $\mathrm{c}$ goes to $\mathrm{a}$.

\section{Upward}

Unordered or

Upward activation

$\mathrm{b})(\mathrm{c}$ from a goes to $\mathrm{b}$ and $\mathrm{c}$.

Downward activation

from b or c goes to a.
Downward

Ordered and

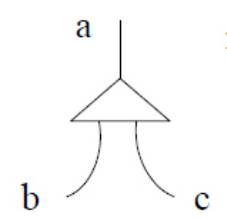

Downward activation

from a goes to $\mathrm{b}$ and later to $\mathrm{c}$.

Upward activation

from $\mathrm{b}$ and later from $\mathrm{c}$

goes to a.
Downward

Ordered or

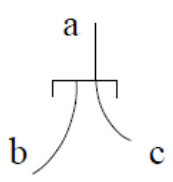

Downward activation from a goes to $b$ if possible, otherwise to $\mathrm{b}$ and later to $\mathrm{c}$.

Upward activation from b or $\mathrm{c}$ goes to a.

Figure 4. Examples of RNT nodes in compact notation (adapted from Lamb, 1999: 67).

These constructs will next be used to model the Spanish pronominal clitic and verb-ending systems and to distinguish the varied types of relationships they include at the semantic, morphological, and morphotactic levels. An ad hoc typographical convention will be used to identify which linguistic level each representation belongs to: semantic categories (e.g., 'number') will take small capitals; semantic features (e.g., 'singular') will be bound by inverted commas; and morphological representations (e.g., lo) will be labeled in italics.

\section{A RNT account of spanish clitics and verb endings}

Spanish clitics are a closed class of representations intermediate between independent words and bound morphemes. The full Spanish clitic paradigm is made up of 11 units, namely: me, nos, te, os, le, les, lo, los, la, las, and se. On the other hand, Spanish verb endings constitute a closed class of bound morphemes, encompassing numerous regular and irregular representations. For the sake of clarity, we shall presently adhere to the convention adopted by García (1975), who uses the endings of the first conjugation of the present indicative as a synecdoche representing the 
endings of all moods, tenses, and conjugation types. Therefore, the verb-ending paradigm considered in the present paper consists of six units, namely: $-0,-s,-\infty,-m o s$, $-i s,-n$.

\subsection{Relationships within and between the semantic and morphological strata}

The systems' morphological units are linked to common semantic categories. Consider example 2, in which a man named Porta talks to a woman named Bárbara:

(2) Porta quería saber si tenía algún amante, pero Bárbara no picó [...]

- Solo contigo - se burló ella.

- No me has contestado.

- No tengo por qué darte explicaciones.

- Yo no te las pido [I do not ask you for them] [RAE: CREA, Matar para vivir].

The clitics (te, las) and the verb ending (-o) in sentence (2) realize various semantic features (García, 1975; Mendikoetxea, 1999; Castel, 2012). First, -o refers to the male 'speaker', te refers to the female 'hearer' and las alludes to 'the explanations' - namely, another participant not directly involved in the conversation (i.e., 'other'). Second, te and -o realize the feature 'singular', whereas las realizes the feature 'plural'. Third, te and las express the feature 'feminine', but -o points to a 'non-feminine' entity. Fourth, the participants realized by the clitics and the verb ending in the sentence have different degrees of activity, ranging from 'most active' ( -0 , in the nominative case) to 'less active' (te, in the dative case) to 'least active' (las, in the accusative case). Also, the clitic las has a greater deictic load than te and -o-unlike the latter, the deixis of las cannot be established by the mere recognition of who is speaking to whom. Thus, las may be said to expound the feature 'high deixis'. Finally, as proposed by García (1975), verb endings tend to bear a greater thematic focus than clitics. In this case, -o is 'thematic', while te and - $o$ are 'non-thematic's

In a specific context of use, a given pronominal clitic or verb ending realizes a constellation of semantic features pertaining to six semantic categories: 'thematic' 'status', 'number', 'gender', 'person', 'deixis' and 'case' (García, 1975). Each of these systems comprises either two or three semantic features. Now, a given clitic or verb ending used in a specific context will realize 'only one' of the features included in each system (see below for an explanation). Thus, the basic semantic relationships for Spanish pronominal clitics and verb endings must be represented with downward unordered 'or' nodes as shown in Figure 5. 


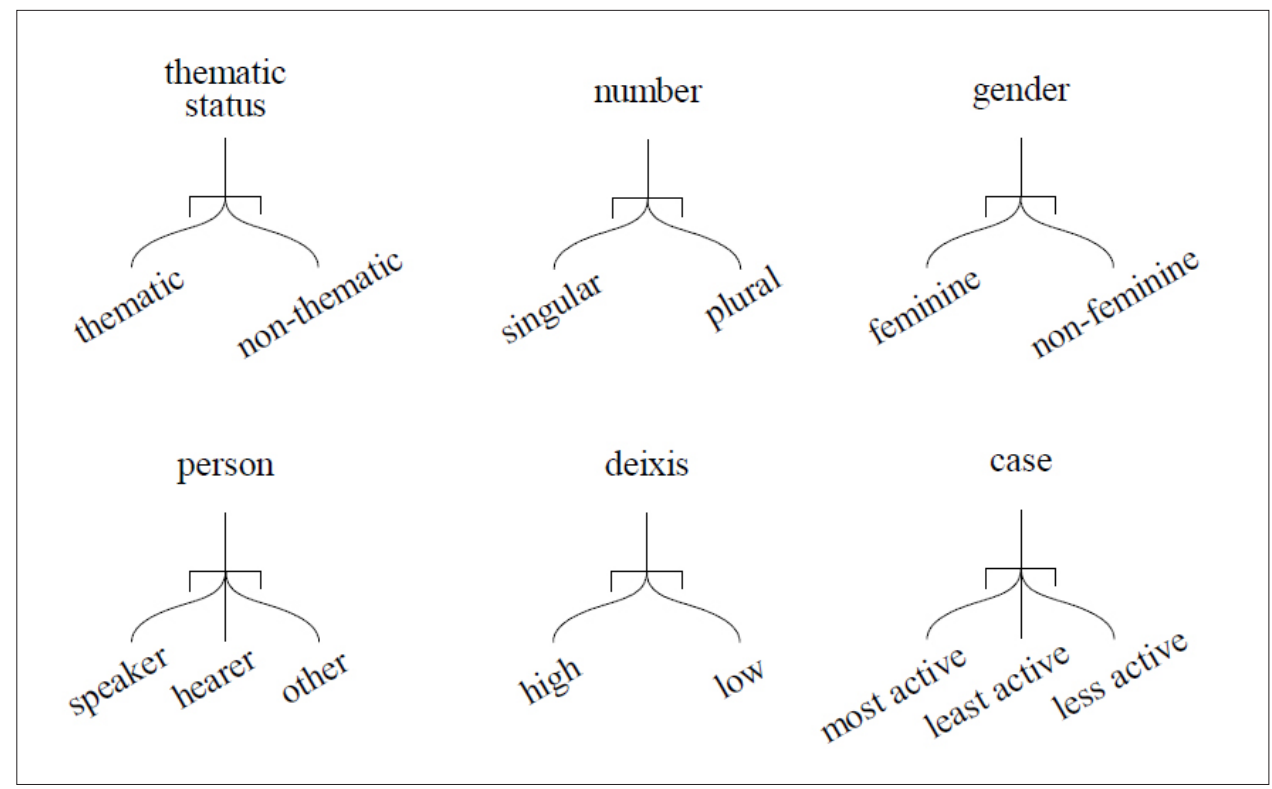

Figure 5. Semantic systems involved in Spanish pronominal clitics and verb endings.

Not every morphological representation of the clitic and verb-ending systems can realize any of the semantic features above. Tables 1-5, adapted from Castel (2012), list all the semantic features that clitics and verb endings necessarily or optionally express.

Table 1. Semantic features of 'person' and 'thematic status' realized by clitics and verb endings.

\begin{tabular}{|c|c|c|c|}
\hline & & \multicolumn{2}{|c|}{ thematic status } \\
\hline & & 'thematic' & 'non-thematic' \\
\hline \multirow{4}{*}{ person } & 'speaker' & $-0,-m o s$ & me, nos \\
\hline & \begin{tabular}{|l|} 
'hearer' \\
\end{tabular} & $-s,-i s$ & te, os \\
\hline & \multirow{2}{*}{ 'other' } & $-0,-n$ & $\operatorname{le}(s), \operatorname{lo}(s), \operatorname{la}(s)$ \\
\hline & & \multicolumn{2}{|l|}{ se } \\
\hline
\end{tabular}

Table 2. Semantic features of 'person' and 'number' realized by clitics and verb endings.

\begin{tabular}{|l|l|l|l|}
\cline { 3 - 4 } \multicolumn{2}{c|}{} & \multicolumn{2}{l|}{ number } \\
\cline { 3 - 4 } \multicolumn{2}{c|}{} & 'singular' & 'plural' \\
\hline \multirow{4}{*}{ person } & 'speaker' & -0, me & - mos, nos \\
\cline { 2 - 4 } & 'hearer' & $-s$, te & $-i s$, os \\
\cline { 2 - 4 } & \multirow{2}{*}{ 'other' } & -0, le, lo, la & $-n$, les, los, las \\
\cline { 3 - 4 } & & se & \\
\hline
\end{tabular}


Table 3. Semantic features of 'person' and 'gender' realized by clitics and verb endings.

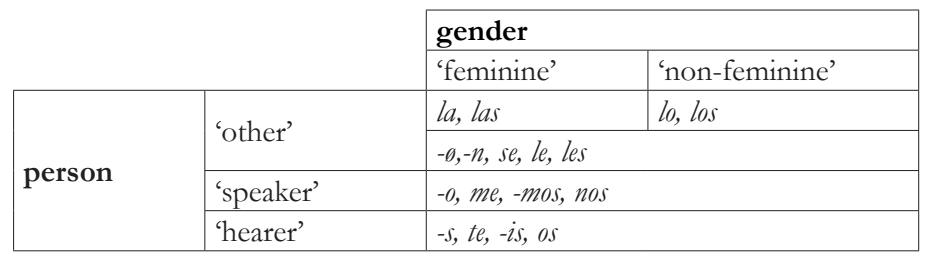

Table 4. Semantic features of 'person' and 'deixis' realized by clitics and verb endings.

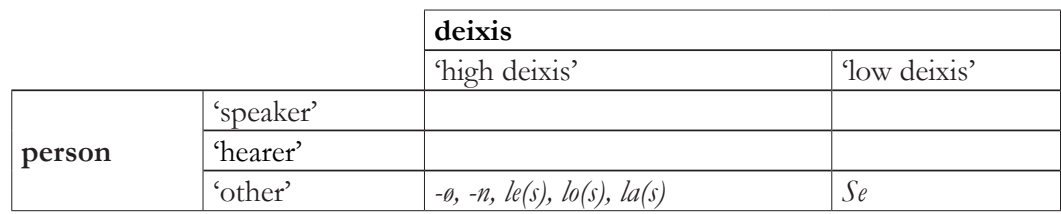

Table 5. Semantic features of 'person' and 'case' realized by clitics and verb endings.

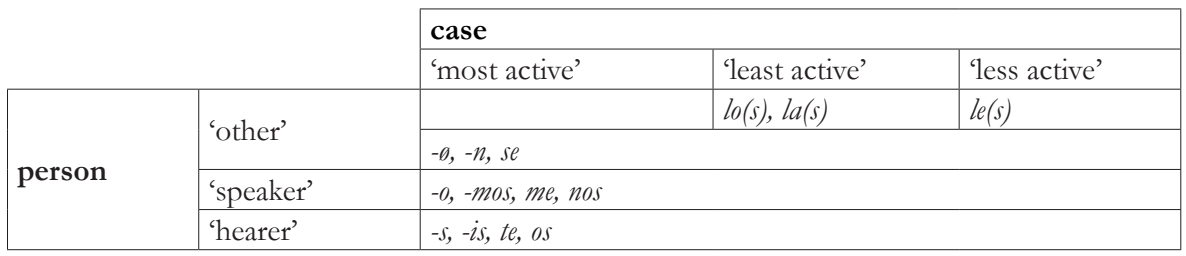

Tables 1-5 make explicit a functional distinction between the 'meanings' some forms necessarily express in every context and the 'messages' some of them may implicitly convey in a specific context. For instance, the feature 'feminine' is a 'meaning' of the clitics la and las in any context, but it is an implicit message conveyed by the clitic le in an example like (3):

(3) [...] ella no lo quería recibir porque ella pensaba que yo le iba a pedir a cambio, alguna cosa una cosa mala, pues [...] Entonces le di el relojy le di la carta [I gave it to her] [RAE: CREA, CSHC-87 Entrevista 60].

Similarly, the ending -o always realizes the meanings 'speaker', 'singular' and 'thematic'. Yet, depending on the context, it will also expound the implicit messages 'feminine' or 'non-feminine', on the one hand, and 'most active', 'less active' or 'least active', on the other. Consider example (4), uttered by a woman in reference to a man called Andrés: 
(4) Si he de lanzarle un dardo a Andrés, que al menos valga la pena el hombre por el que se $1 \mathrm{o}$ lanzo [I throw it to him].

- ¿Has pensado en el foso medieval como un símbolo de libertad? -le pregunto.

- No. Pero estoy abierto a pensarlo, si me convences.

- ¿Sabes, Javier, que a nosotras las mujeres nos han enseñado a temerle a la soledad? [RAE: CREA, Antigua vida mía].

In this particular case, the ending $-o$ conveys the messages 'feminine' and 'most active'. The latter feature can only be inferred by virtue of the participant role structure implied by the process 'lanz', which indicates that the obligatory participant 'actor' (some of whose semantic features are replicated by -0 , in reference to the female speaker) will have a more active role than the obligatory participant BENEFICIARY (expounded by se, in reference to Andrés).

So far, we have seen that the Spanish clitic and verb-ending systems involve different types of connections between their semantic and morphological representations. As seen in Figure 5, each semantic category is organized as a series of disjunctions between its relevant features. Also, whereas some of those features are necessarily evoked by a given clitic or verb ending as 'meanings', others can only be implied as 'messages'. Finally, in a specific context of use, each clitic and verb ending realizes six semantic features simultaneously. All these varied connections are formally captured by the relational network in Figure 6, whose thick lines represent the connections active in the processing of the clitics and verb endings of the sentence se lo lanzo (i.e., se, $l o$ and -0 ). 


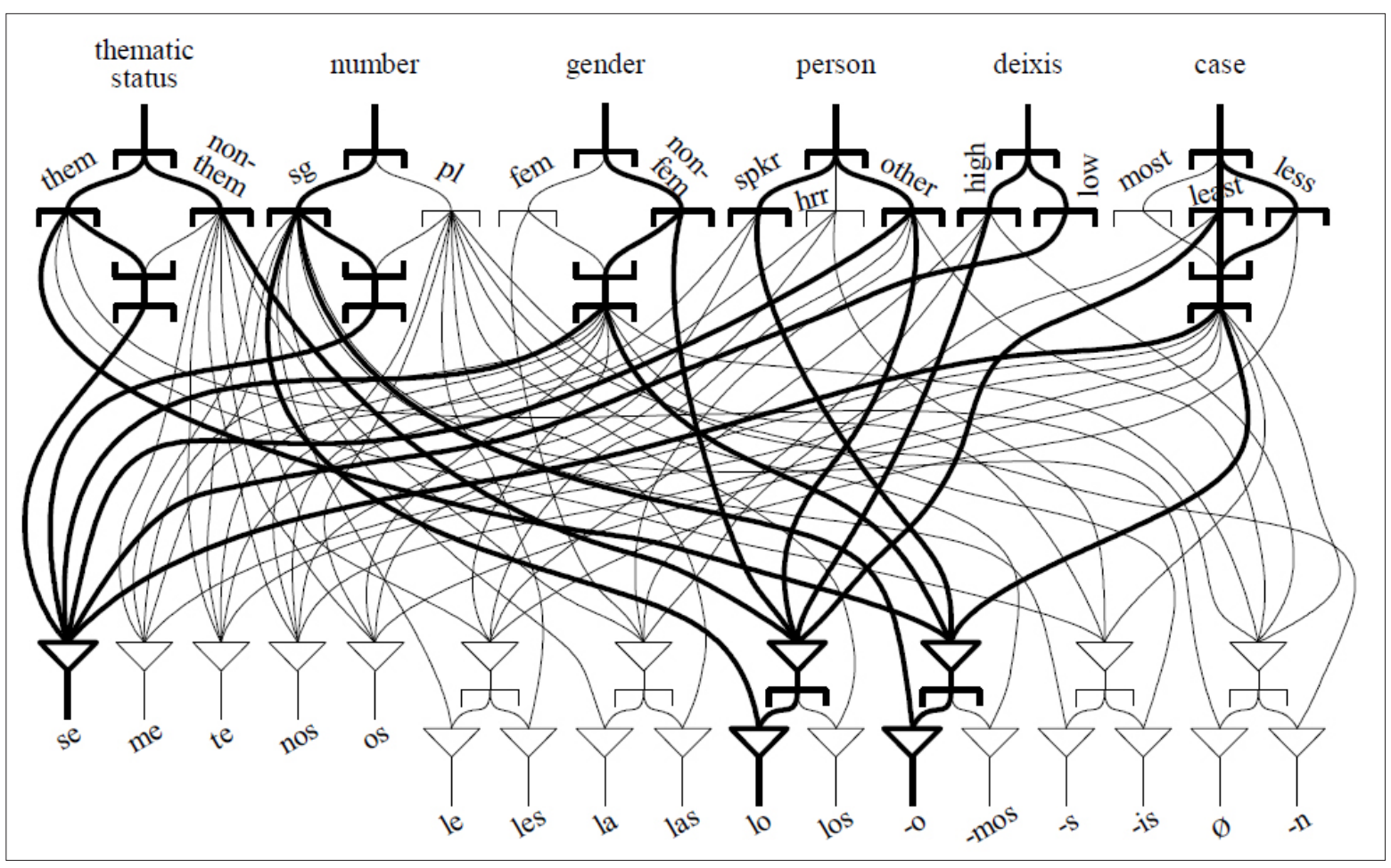

Figure 6. Semantic and morphological representations of the Spanish pronominal clitic and verb-ending systems in relational-network terms.

The network in Figure 6 captures all the connections between the systems' semantic and morphological representations. Each semantic category (e.g., 'thematic status', 'number') and feature (e.g., 'thematic', 'non-thematic', 'singular', 'plural') is represented by a downward unordered 'or' node, indicating that they can be connected with multiple morphological representations in both systems. Morphological elements are represented by upward unordered 'and' nodes, since the semantic features they evoke or can evoke are activated simultaneously rather than sequentially. For example, the clitic se in example 4 simultaneously activates the features 'thematic', 'singular', 'non-feminine', 'other', 'low deixis' and 'less active'. Each possible constellation of semantic features involves a specific pattern of connections leading to the activation of its corresponding morphological realization.

Furthermore, this network formalizes the distinction between explicit 'meanings' and implicit 'messages' (Figure 7). 'Meanings' are represented by downward unordered 'or' nodes stemming directly from their corresponding semantic category label. Instead, 'messages' are represented by complex 'or' node structures in which an upward unordered 'or' node can be activated by either of its incoming lines so as to then activate a downward unordered 'or' node which will, in turn, send further activation to a specific clitic or verb ending. 


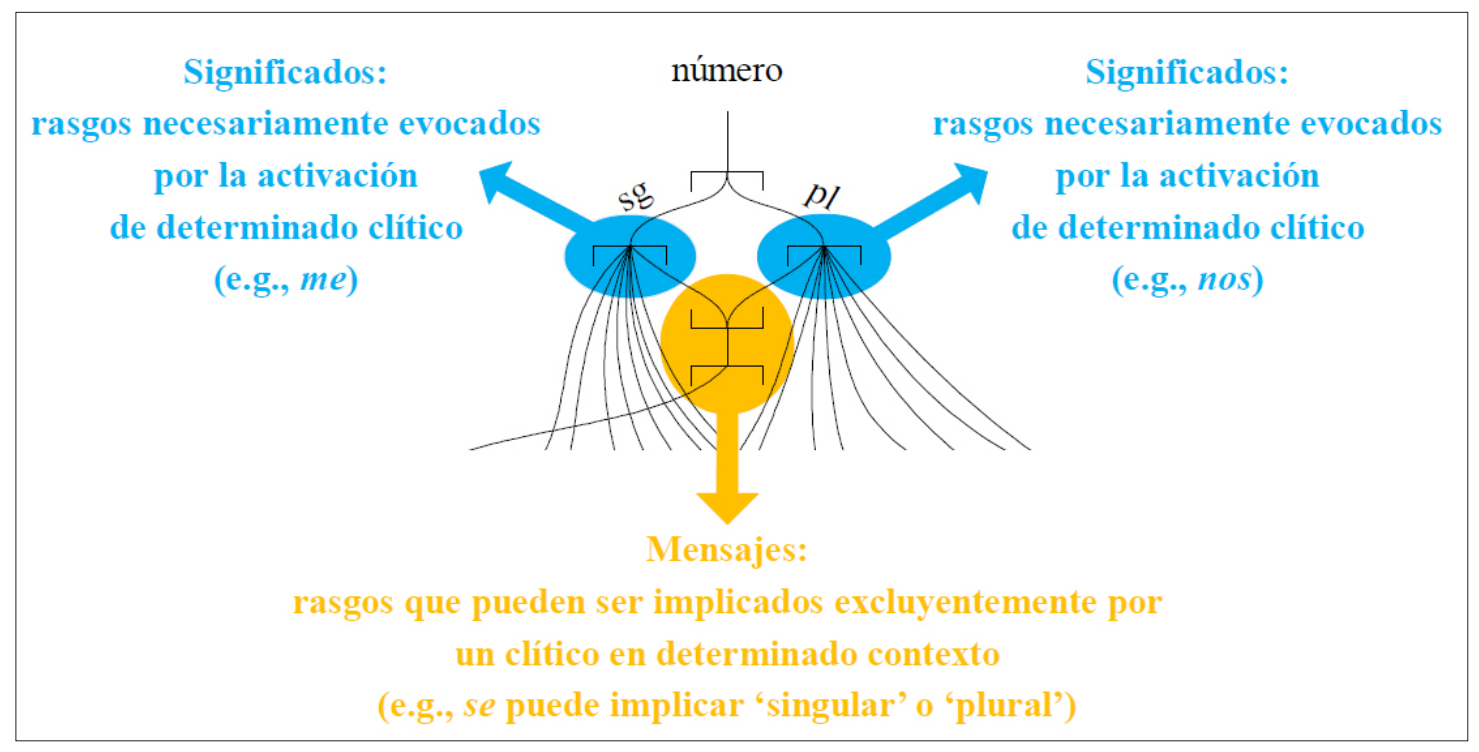

Figure 7. Relational distinction between context-independent meanings and contextdependent messages in the Spanish pronominal clitic and verb-ending systems.

\subsection{The systems' morphotactics and its integration with their semantic aspects}

The network in Figure 7 does not specify the syntactic (viz., morphotactic) constraints of the Spanish clitic and verb-ending systems. Of course, not any clitic can occur in any position. For example, the pseudo-sentence * lo se lanzo, violates the morphotactic restriction that se cannot occur after another clitic. If, as postulated within RNT, 'all' linguistic information is relational, then morphotactic patterns and restrictions must also be characterized as networks of relationships among different nodes. The relational network in Figure 8 represents the main connections involved in the morphotactics of the Spanish clitic and verb-endings systems. Once again, for the sake of illustration, the connections active in the processing of the sentence se lo lanzo are drawn with thicker lines. 


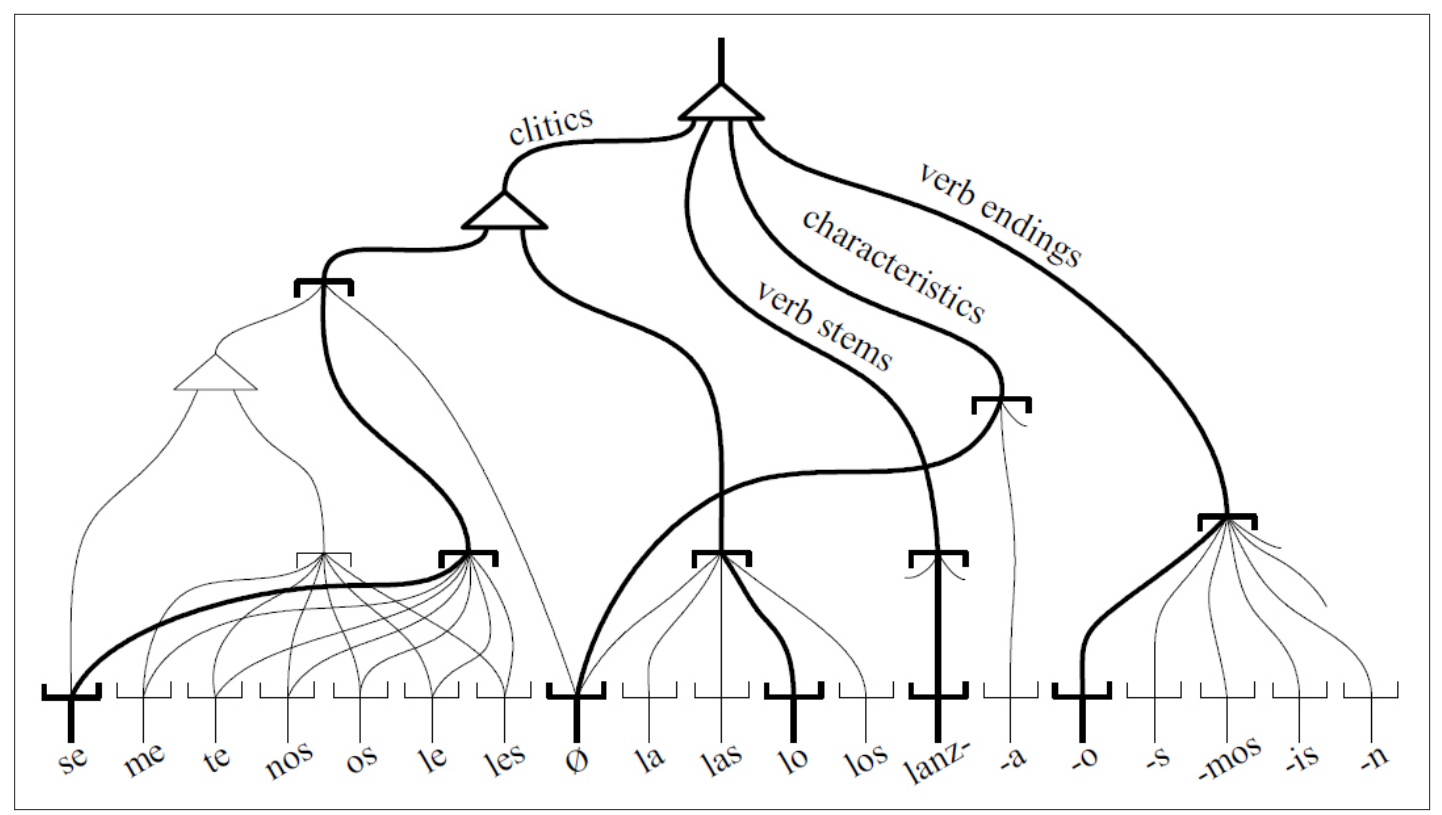

Figure 8. A morphotactic network for Spanish pronominal clitics and verb endings.

Figure 8 presents a 'partial' morphotactic network for the systems. It includes ordering constraints for the indicative and subjunctive moods only. It omits the connections involved in the processing of clitics and verb endings in the imperative mood and in infinitival and gerundial forms, all of which require clitics to function as suffixes. Neither does the network include the connections needed to account for the processing of patterns like me le/les (lanzo), te le/les (lanzas), os le/les (lanzáis) and nos le/les (lanzamos). Also, notice that the present model refers only to pronominal clitics. Clitics used in impersonal constructions (e.g., se vende este auto, se lo detiene) fall outside the scope of this paper.

Such simplifications notwithstanding, the network in Figure 8 elegantly accounts for several key aspects of the systems morphotactics. The downward ordered 'and' node at the top of the figure indicates that (for the indicative and subjunctive moods) morphological representations are always activated in this sequence: (i) clitics, (ii) verb stems, (iii) characteristics; and (iv) verb endings. In processing the sentence se lo presto (thick lines), the first downward ordered 'and' stemming from the connection for clitics shows that the form se is activated first and that the form $l o$ is activated afterwards -the downward 'or' nodes represent other possible but presently inactive morphotactic patterns. Then, the connection for verb stems leads to a downward unordered 'or' node which can then activate any verb stem -the network includes only the stem prest- so as not to clutter the network with too many lines. The connection for characteristics leads to another downward unordered 'or' which presently results in the activation of $\emptyset$. This means that in processing the sentence in question there 
is no morphological form which on its own realizes the semantic features 'mood', 'tense' and 'aspect' (i.e., the verb's characteristics). Such values are all realized by the ending -o. Finally, the downward unordered 'or' for verb endings leads to the activation of -0 . Note that all morphological units in the network are represented by upward unordered 'or' nodes, indicating that one and the same morpheme may be activated by different connections -i.e., in different structural positions.

Now, the networks in Figures 7 and 8 do not operate separately; rather, activation flows travel through them at the same time in the processing of a given sentence. In this sense, Figure 9 illustrates the integration of both networks -only the semantic connections of the clitic se are included, lest the network proves unintelligible due to the inclusion of too many lines.

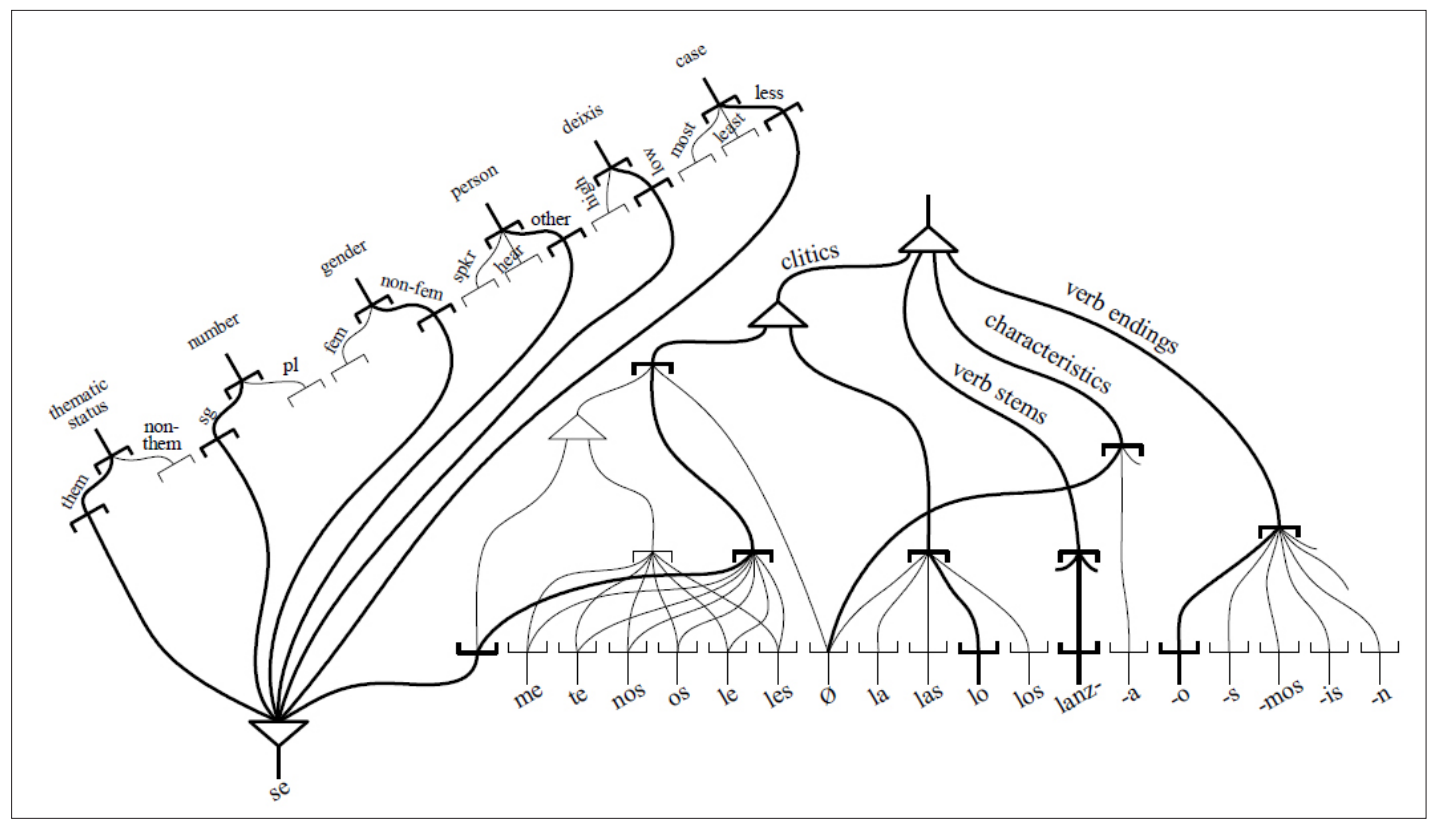

Figure 9. An integrative RNT model of se in the context of se lo lanzo.

\section{Analyzing the networks}

The RNT model presented above has several distinctive features. First, the relational networks of Figures 6, 7, 8, and 9 are bidirectional in nature. Designed in compact notation, they can be traveled downwards (for production processes) and upwards (for comprehension processes), regardless of the orientation of the nodes involved. Hence, they constitute descriptions of the cognitive structures operative not only in the conveyance of meanings and the implication of messages by a speaker, but also in the interpretation of such semantic representations by a hearer. ${ }^{5}$ 
Second, the networks reflect the fact that the relationships within the clitic and verb-ending systems are not monolithic. Four distinct types of connections have been identified in different portions of the systems: (i) the relationships between a semantic category and its associated features are disjunctive (e.g., between 'gender' and 'feminine' and 'non-feminine'), thus involving 'or' nodes; (ii) whereas explicit, context-independent 'meanings' involve simple downward 'or' nodes, implicit, context-dependent 'messages' call for complex disjunctive relationships in which an upward 'or' node is then connected to a downward 'or' node; (iii) the relationships representing morphotactic patterns are sequential conjunctions (e.g., the mother node in Figure 8, determining the serial order of 'clitics', 'verb stems', 'characteristics' and 'verb endings'), thus involving ordered 'and' nodes; and (iv) the relationships established between a constellation of semantic features and the morphological representation realizing it in a specific context of use are simultaneous conjunctions (e.g., each set of semantic activations converging in the upward unordered 'and' nodes appearing at the bottom of Figure 6), thus involving unordered 'and' nodes.

Third, the networks formalize a connectionist account of morphotactics which does away with rules, transformations, displacement operations, and other constructs of questionable cognitive plausibility (Lamb, 1999). The present model characterizes the morphotactics of clitics and verb endings by virtue of connections and flows of activation traveling along those connections. Consequently, the semantic, morphotactic, and morphological representations of both systems are processed by the same type of cognitive mechanism: flows of dynamic signals leading to the concerted activation of specific patterns of nodes. As regards the systems' morphotactics, what determines the relative order of the representations in sentence processing is the specific pattern of sequential and disjunctive connections in the morphotactic network. In such a network, the activation of each ordered 'and' node triggers multiple obligatory sequential connections, whereas 'or' nodes lead to several paradigmatic options within the clitic and verb-ending systems.

Fourth, the networks lack nodes redundantly representing 'the same information'. For instance, the fact that a given semantic feature (e.g., 'singular') is activated in the processing of different morphological representations (e.g., se, lo and -o) is modeled by the presence of multiple differential connections leading from the former to the latter. In other words, the realization of the same information by different units is represented via constellations of relationships specific to each of those units. If each morphological representation were connected to its own (redundant) set of features in the semantic system, there would be no reason to postulate a separation between the semantic and the lexicogrammatical strata.

Lastly, the relational networks presented in this paper-as well as any other relational network-include no symbols or static objects in their structure. In RNT terms, the individual cognitive system consists only of relationships. The labels placed next to the networks' lines are mere visual aids for model builders or readers to know which 
part of the system is being described. It would be a mistake to think of such labels as part of cognitive structure proper. It would also be wrong to conceive of nodes as the iconic correlate of an analytic symbol. Lamb (1999) sheds light on this point with the following analogy: symbols are to a cognitive system what road signs are to a highway. The road sign reading "New York 80 miles" is not part of the highway system proper. The sign (i.e., the symbolic label) can be removed without the highway (i.e., the system of connections) suffering any change in its structure. Symbols are nothing but signaling epiphenomena. The only elements which are part of the system proper are the connecting lines and the nodes representing specific points of contact between particular patterns of connections. Based on these premises, the present model of the Spanish clitic and verb-ending systems is a purely connectionist one.

\section{DISCUSSION AND CONCLUSION}

Castel (2012) has made a valuable contribution to the functional-cognitive literature by formulating a network model of the interface between meaning and form representations. In doing so, he has proposed what seems to be the first connectionist account of the functional-cognitive structure underlying the Spanish clitic and verb-ending systems. However, his network approach features a number of limitations. The present paper has relied on RNT to overcome such limitations and foster progress in this line of research.

Specifically, a formal distinction has been proposed among the varied types of relationships allowing for information processing in relevant systems. Level-specific differences in connectivity have been detected between (i) semantic categories and features (downward 'or' nodes), (ii) context-independent meanings and contextdependent messages (simple vs. complex 'or' node structures), (iii) morphotactic patterns and morphological representations (downward ordered 'and' nodes), and (iv) semantic features and morphological representations (upward unordered 'and' nodes).

This RNT-based account seems to overcome some of the main drawbacks of Castel's (2012) approach, framed within the CMM (Fawcett, 2011, 2013). First, Castel's (2012) networks are unidirectional, as they account only for the connections involved in sentence production. While the CMM does include a module to account for the logical operations and mechanisms involved in sentence parsing (Fawcett, 2011, 2013), these have not been contemplated in Castel's (2012) account. On the other hand, the present RNT model accounts for both production and comprehension processes, thus representing the cognitive structures which support the conveyance of meanings/messages and their interpretation.

Second, the RNT model is more explicit in its discrimination of different connection types. The nodes and connections in Castel's (2012) specify that a representation A is linked to a representation B, but no further connectivity details are offered. Instead, the RNT network explicitly captures the fact that the Spanish clitic and verb-ending 
systems involve varied types of connections, as detailed above. While Castel's (2012) approach does recognize the existence of different relationships among strata, these are specified only in the realization rules underlying the network (Castel, 2012), but they are not visible in the network per se. In this sense, the RNT network seems superior in satisfying the requirement of visual explicitness.

A third difference concerns the conception of syntax. Castel's (2012) approach accounts for morphological ordering by inserting objects into abstract slots in a predetermined syntactic scheme. The underlying assumption is that somewhere in the production system of the communicative mind lies an abstract space comprising hundreds of slots which can be filled or left empty as dictated by realization rules. The cognitive plausibility of this view is, at least, dubious (Lamb, 1999). On the contrary, the RNT network presupposes no rules or filled/empty slots, as it characterizes morphotactics via the same type of connectionist constructs used to account for relationships among representations. In this sense, rather that positing ontologically different mechanisms for semantics and lexicogrammar, the RNT approach characterizes all relevant relationships by means of connections and flows of activation patterns through them.

Finally, Castel's (2012) network implies that the same linguistic information exists multiple times in the system (e.g., there are three different nodes representing the feature 'singular'). It follows that, in the production of a sentence such as me le regalo, the speaker would be activating different semantic nodes to process the very same information. Instead, the RNT network proposes that each feature is represented only once, and that one and the same node may be activated in processing varied lexical/ morphological representations, even within the same sentence. Thus, each clitic and verb ending which expresses the meaning (or may imply the message) 'singular' has its own connection to such a unique feature. The RNT network seems to possess two advantages in this regard. On the one hand, it constitutes a more elegant account, as the same observational domain is characterized with greater representational economy. On the other hand, it seems more linguistically plausible. If each lexicogrammatical representation were actually connected to its own redundant representation in the semantic system, there would be no reason to postulate a separate semantic stratum in the first place. The very idea of realization (a cornerstone of the two approaches discussed in this paper) seeks to reflect two aspects of language structure: (i) the fact that one and the same constellation of semantic features may be expressed, at least partially, through different lexicogrammatical units; and (ii) the fact the different constellations of semantic features may be expressed by the same lexicogrammatical unit.

More generally, the present RNT model presents a crucial conceptual difference relative to the approach followed by Castel (2012) and other systemic-functional models. The latter perspectives posit an ontological distinction between the meaning 
and the form potentials. These two are described separately, through the use of different conceptual tools. For instance, in the CMM (Fawcett, 2011, 2013), the semantic potential is organized in terms of system networks, but the form potential involves serial realization rules (see Figure 1). Thus, the mechanisms operating at each of those strata are proposed to depend on different cognitive organizations and operations. Moreover, instances of meaning and form are handled by modules different from those representing meaning and form potentials, respectively. On the contrary, the present RNT approach makes no such ontological distinction. Linguistic instances are activated 'within' the linguistic potentials. In other words, for the RNT account, an instance (of meaning or form) is nothing but the constellation of (potential) representations effectively active in a given context of use. In this way, it does away with the dubious notion that the 'communicative mind' includes separate sets of representations for linguistic potentials and linguistic instances.

Evidently, each network -and, more generally, each of their underlying theoriesis rooted in different conceptions of the human mind. For the CMM framework, the plausibility of a cognitive model depends on whether it can be emulated by a computer.

"Indeed, it is probably time for linguists to reconsider our traditional assumptions about what makes a model 'elegant' [...] [I]t may be that we should not condemn as 'inelegant' or 'uneconomical' rules that the conscious human mind finds somewhat difficult to implement, but which can be performed by a computer in a moment -and also, some might wish to add, whose analogues in human brain can similarly be performed in a trice and, moreover, without requiring conscious attention" (Fawcett, 2003: 13).

On the other hand, in RNT terms, a linguistic model will be acceptable only if it meets the three requirements of operational, developmental, and neurological plausibility (cf. section 1). Unlike the CMM, RNT posits a connectionist, paralleldistributed conception of mental processes, in line with current trends in cognitive science (Gazzaniga, 2009).

However, the present RNT account is not without limitations of its own. Crucially, the proposed network does not handle all possible clitic and verb-ending patterns. It would be interesting to expand the present description to include gerundial and imperative forms, for example. Also, other RNT models of the same systems may be proposed, opening the possibility for more elegant accounts. In particular, the present networks are intended to account for (a subset of) Spanish clitics and verb endings at the single-sentence level. Further analyses should be conducted to develop networks capable of handling textual phenomena beyond the production of individual sentences (e.g., the establishment of cohesive ties between clitics and noun phrases as multi-sentential texts unfold in real time). 
Note that certain aspects of the systems herein described are subject to theoretical debates. For instance, several authors (Aissen \& Rivas, 1975; Fernández Soriano, 1999) have advanced conflicting views on the nature of the spurious se (i.e., the systematic use of se $l o$ instead of the non-occurring cluster *le lo). The present model accounts for such a cluster at the morphotactic level (Figure 8), with additional restrictions coming from the semantic stratum (Figure 9). This solution is consistent with the framework advanced by García $(1975,2009)$. According to this author, the impossibility of processing the cluster *le lo follows from the same principles underlying the acceptable use of other clitics, be it in isolation or in clusters. In her own words,

"se lo is easier to process than le lo, for the diversification of the references allows the two 3rd ps participants to be identified in the cognitively most economic order, i.e. first the Central, and then the Peripheral participant [...] It is neither conventional use nor morpho-phonological dissimilation that makes *le lo yield to se lo: se $l o$ is preferable to le lo for essentially the same reasons that me presentaste a ella is preferable to me le presentaste in conveying 'You introduced me to her"'(García, 2009: 142).

Yet, there are alternative conceptions of the phenomenon. For example, Bonet (1995) and Harris (1996) propose that this restriction reflects morpho-phonotactic processes, whereas Menn and MacWhinney (1984), Fernández Soriano (1999), and Sharp (2005) conceive of the spurious se as an instance of arbitrary morphophonological dissimilation. Although this paper does not seek to contrast opposing theoretical perspectives, note that RNT allows to model divergent conceptions of the same phenomenon. The morpho-phonological account of the spurious se, for example, might be represented through the network in Figure 10. 


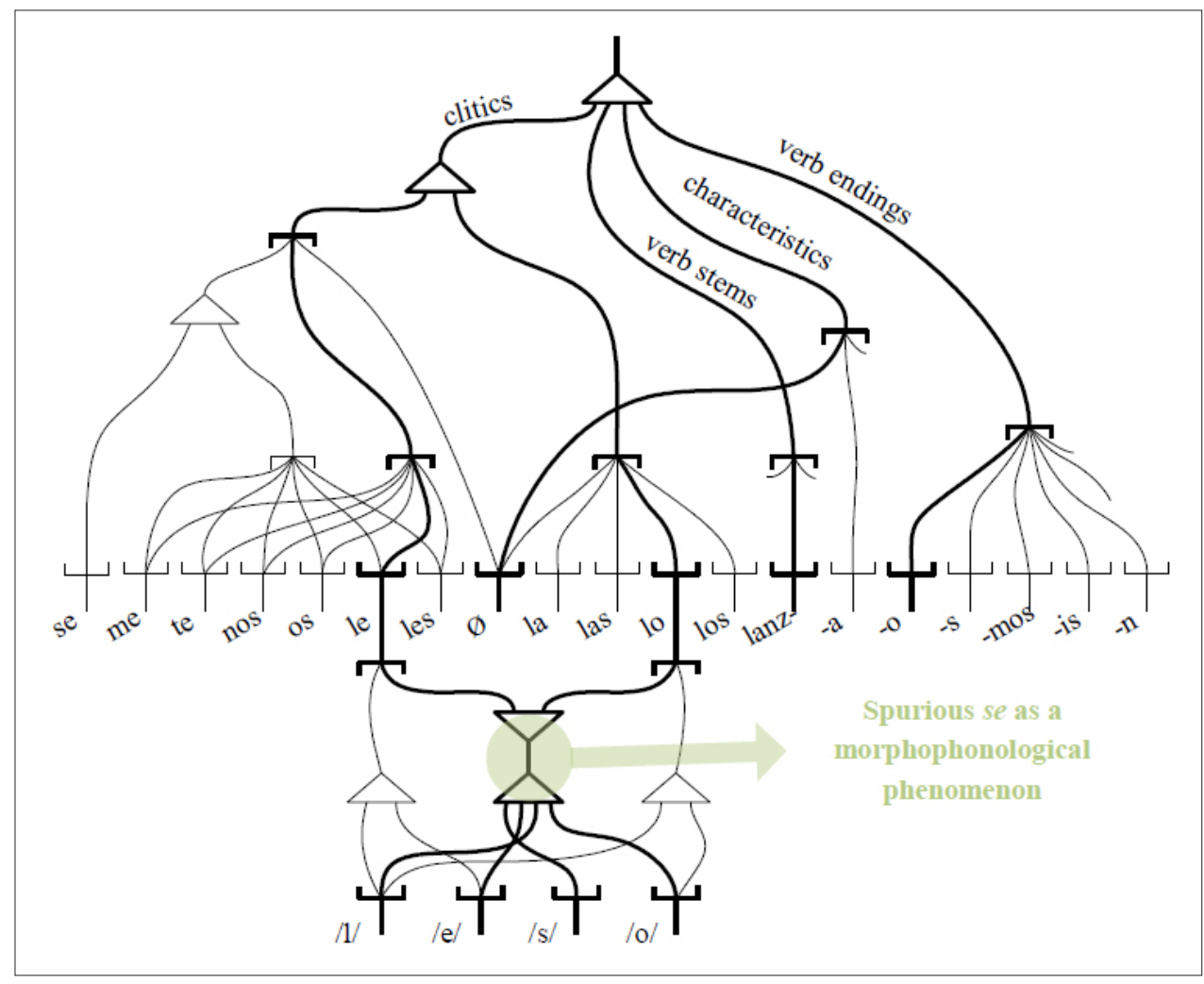

Figure 10. A morpho-phonological account of the spurious se.

Finally, the question also remains whether the RNT models proposed are neurologically plausible. While Lamb (1999) explicitly proposes possible neural correlates for the constructs included in RNT, it cannot be assumed that any relational network model of a given cognitive system is necessarily plausible in neurological terms. Finally, further research is also necessary to verify whether these networks can be computationally implemented to dynamically model linguistic processing. In this sense, the Neurocognitive Linguistics Lab software ${ }^{6}$ and the Ph.D. thesis by Harrison (2000) may prove to be valuable resources. This is an aspect in which Castel's (2012) approach proves superior, as it has been computationally implemented and allows for the automatic generation of networks for any combination of clitics.

All in all, this paper highlights the contributions that an explicit network model can make in the cognitive study of linguistic systems. By offering tools to differentiate among varied types of nodes and connections, RNT may be a useful approach to guide theoretical and empirical research within functional-cognitive linguistics. 


\section{REFERENCES}

Aijón Oliva, M. A. \& Serrano, M. J. (2010). Las bases cognitivas del estilo lingüístico. Sociolinguistic Studies, 4(1), 115-144.

Aissen, J. \& Rivas, A. M. (1975). The proper formulation of the spurious se rule in Spanish. Berkeley Linguistics Society, 1, 1-15.

Bello, A. (1980). Gramática de la lengua castellana. Madrid: EDAF.

Belloro, V. A. (2007). Spanish clitic doubling: A study of the syntax-pragmatics interface. Ann Arbor, MI: ProQuest.

Bonet, E. (1994). The person-case constraint: A morphological approach. MIT Working Papers in Linguistics, 22, 33-52.

Bonet, E. (1995). Feature structure of Romance clitics. Natural Language and Linguistic Theory, 13, 607-647.

Castel, V. M. (2012). Sobre la visibilidad de significados y mensajes en la relación entre léxico y morfosintaxis. In M. Giammatteo, L. Ferrari \& H. Albano (Eds.), Léxico y sintaxis (pp. 161-182). Mendoza: Editorial FFyL-UNCuyo y SAL.

Enrique-Arias, A. (2005). When clitics become affixes, where do they come to rest? A case from Spanish. In W. U. Dressler, D. Kastovsky, O. E. Pfeiffer \& F. Rainer (Eds.), Morphology and its Demarcations (pp. 67-79). Amsterdam: John Benjamins.

Fawcett, R. P. (2000). A theory of syntax for systemic functional linguistics. Amsterdam: John Benjamins.

Fawcett, R. P. (2003). A generative systemic functional micro-grammar for some central elements of the English Clause. Cardiff UK: Computational Linguistics Unit, Cardiff University.

Fawcett, R. P. (2011). Alternative architectures in systemic functional grammar. How do we choose? London: Equinox.

Fawcett, R. P. (2013). An integrative architecture of language and its use for systemic functional linguistics and other theories of language. London: Equinox.

Fernández Soriano, O. (1999). El pronombre personal: Formas y distribuciones. In I. Bosque \& V. Demonte (Eds.), Gramática descriptiva de la lengua española (pp. 1209-1272). Madrid: Espasa Calpe.

García, A. M. (2012). La Teoría de Redes Relacionales: Correlatos neurológicos de un modelo lingüístico conexionista. Onomázein, 26, 221-257. 
García, A. M. (2013). Relational network theory as a bridge between linguistics and neuroscience: An interview with Professor Sydney Lamb. Linguistics and the Human Sciences, 8(1), 3-27.

García, A. M. \& Gil, J. M. (2011a). A historical survey into the origins of Lambian linguistics. LACUS Forum, 36, 111-123.

García, A. M. \& Gil, J. M. (2011b). Una perspectiva sistémico-funcional del español: Acerca de la multifuncionalidad en la cláusula castellana simple. Revista de Investigación Lingüistica, 14, 191-214.

García, E. (1975). The role of theory in linguistic analysis. The Spanish pronoun system. Amsterdam: North-Holland Publishing Company.

García, E. (2009). The motivated syntax of arbitrary signs. Cognitive constraints on Spanish clitic clustering. Amsterdam/Philadelphia: John Benjamins.

Gazzaniga, M. (Ed.) (2009). The cognitive neurosciences. Massachusetts: MIT Press.

Gil, J. M. \& García, A. M. (2010). Transitividad, Modo y Tema en español: Un primer análisis en términos de la gramática de Cardiff. Revista Signos. Estudios de Lingüistica, 43(72), 71-98.

Harris, J. (1996). The morphology of Spanish clitics. In H. Campos \& P. Kempchinsky (Eds.), Evolution and revolution in linguistic theory: Essays in honor of Carlos Otero (pp. 168-197). Washington D.C.: Georgetown University Press.

Harrison, C. J. (2000). PureNet: A modeling program for neurocognitive linguistics. Doctoral thesis, Michigan: Bell \& Howell Information and Learning.

Haspelmath, M. (2004). Explaining the ditransitive person-role constraint: A usagebased approach. Constructions, 2, 1-71.

Hjelmslev, L. (1961 [1943]). Prolegomena to a theory of language (translated by F.J. Whitfield). Madison: University of Wisconsin Press.

Lamb, S. (1966). Outline of stratificational grammar. Washington, D.C.: Georgetown University Press.

Lamb, S. (1980). A new look at phonotactics. In J. Copeland \& P. Davis (Eds.), Papers in cognitive-stratificational linguistics (pp. 1-18). Houston: Rice University.

Lamb, S. (1999). Pathways of the brain: The neurocognitive basis of language. Amsterdam: John Benjamins.

Lockwood, D. (1972). Introduction to stratificational linguistics. New York: Harcourt Brace Jovanovich. 
Marshall, C. (2006). A relational network perspective of diachronic linguistics: A case study of the French genitive. LACUS Forum, 32, 119-132.

Martínez, A. (2010). De España a América: Recategorización y desplazamientos en el sistema de clíticos. Olivar: Revista de literatura y cultura españolas, 14, 149-162.

Mendikoetxea, A. (1999). Construcciones con se: Medias, pasivas e impersonales. In I. Bosque \& V. Demonte (Eds.), Gramática descriptiva de la lengua española (pp. 1631-1722). Madrid: Espasa Calpe.

Menn, L. \& MacWhinney, B. (1984). The repeated morph constraint: Toward an explanation. Language, 60, 519-541.

Piera, C. \& Varela, S. (1999). Relaciones entre morfología y sintaxis. In I. Bosque \& V. Demonte (Eds.), Gramática descriptiva de la lengua española (pp. 4367-4422). Madrid: Espasa Calpe.

Real Academia Española. CREA: Corpus de referencia del español actual [en línea]. Disponible en http://www.rae.es

Sharp, R. (2005). A unified treatment of Spanish se. In A. Branco, T. McEnery \& R. Mitkov (Eds.), Anaphora Processing (pp. 113-136). Amsterdam: John Benjamins.

\section{NOTES}

1 However, the relationships between clitics and verb endings to each of these semantic categories are not exactly the same (see 2.1).

2 The values of MOOD, TENSE, and ASPECT may be expressed by separate morphemes (verb characteristics).

3 RNT has seldom been used to describe particular languages. A relational description of Czcech can be found in Lockwood (1972); several parts of English grammar have been described by Lamb (1966, 1980, 1999); and aspects of genitive constructions in Latin and French have been approached modelled by Marshall (2006). The paucity of RNT-based accounts of specific languages may be partly due to the qualms Lamb himself has expressed regarding the usefulness of his theory for describing particular languages (García, 2013).

4 By choosing a particular wording, the speaker ascribes different degrees of interest to the entities involved in the event he/she is construing. In this functionalist framework, the notion of thematic status refers to how focal a participant is for the process at hand. By realizing features within the systems of PERSON and NUMBER, verb endings denote the participant from whose perspective the event is seen. This privileged position renders such a participant thematic. As seen in Table 1, all verb endings stand in paradigmatic opposition to clitics other than se. Thus, the referents of such clitics are non-focal, or non-thematic. Finally, the thematic status of se must be contextually inferred (for details, see García, 1975, 2009). For further details regarding why more than one element may bear thematic status in the Spanish clause, see Gil and García (2010), García and Gil (2011b).

5 All the networks in this paper can be converted into narrow notation, a notation system decomposing bidirectional compact nodes into pairs of unidirectional nodes running in opposite directions (Lamb, 1999). This would be desirable if the model were to seek neurological plausibility (García, 2012).

6 The software is available for free download at https://bitbucket.org/kulibali/neurocogling/wiki/ Home 